\title{
MBR+ROを用いた電子産業向け排水回収システム
}

\author{
佐藤祐也 \\ オルガノ株式会社＼cjkstart開発センター \\ 干 252-0332 神奈川県相模原市南区西大沼 4-4-1
}

\section{The Wastewater Reclamation System of MBR+RO for Electronic Industry}

\author{
Yuya Sato \\ Organo Corporation \\ 4-4-1, Nishi-onuma, Minami-ku, Sagamihara-shi, Kanagawa 252-0332, Japan
}

Recently, the wastewater reclamation system has been popular in the electronic industry field, not only for inorganic wastewater but also for organic wastewater that is difficult to reclaim. We tried the reclamation test for the electronic industry organic wastewater using MBR and RO system.

In this test, the quality of the final treated water (RO permeate) is less than $100 \mu \mathrm{S} / \mathrm{cm}$ for electronic conductivity and about $0.5 \mathrm{mg} / \mathrm{L}$ for TOC. We could obtain the enough water quality for the makeup water of a cooling tower. Moreover, MBR and RO have been operated very stably in this test period.

Key words : membrane bio-reactor / reverse osmosis / electronic industry / wastewater reclamation

\section{1. はじめに}

全世界的な水不足の懸念から, 海水淡水化や排水 回収などの，いわゆる造水技術が注目を浴びている. 例えばよく知られているシンガポールの NEWater プ ロジェクトでは，生活排水や工場排水を処理して， 工業用水や間接的な飲用水として再利用するプロジ エクトが進行している1 3).

海外はもちろん，日本国内であっても，排水回 収・再利用の動きは活発である。電子産業分野にお いては，大量の超純水を使用するため，当然排水量 も大量となる. Fig. 1に, 電子産業工場における代表 的な水処理プロセスを示した，従来は無機系排水を 中心に, 希薄系排水は純水として, 濃厚系排水は雑 用水として回収再利用がされてきたが，最近では工 場のさらなる水回収率向上のために, 処理が難しい

Tel: 042-702-7825

Fax: 042-702-7845

E-mail: sato-yu@organo.co.jp
とされてきた有機系排水の回収再利用も行われてい る. その背景には, 液晶パネル工場をはじめとする 設備の大型化による超純水使用量のさらなる増加や, 取水・放流の制限やコストの増加などがあるが，有 機系排水回収にも適用できる技術の進歩 ${ }^{4}$, 実用例の 増加なども大きな要因である ${ }^{5 \sim 7)}$.

本報では，電子産業向け有機系排水回収に焦点を 当て, 膜分離活性污泥法 (MBR法) および逆浸透膜 法（RO 膜法）による排水回収システムを用いて, 実 際の工場排水を処理した試験例を紹介する.

\section{2. 試験内容}

\section{1 試験の背景}

本試験では，電子産業系顧客からの要望に基づき， 下水放流コストの削減抢よび工水使用量の削減を目 的として, 従来排水処理設備で処理後に下水放流し ていた下水放流水を, MBRおよびROによって処 理・回収が可能かどうかを検証した。回収水は, ク ーリングタワーの補給水としての利用を想定した。 


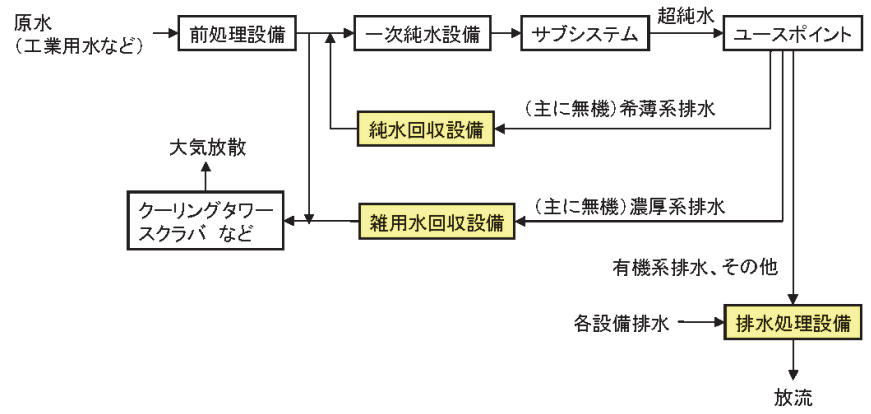

Fig. 1 The process of water treatment for electronic industry.

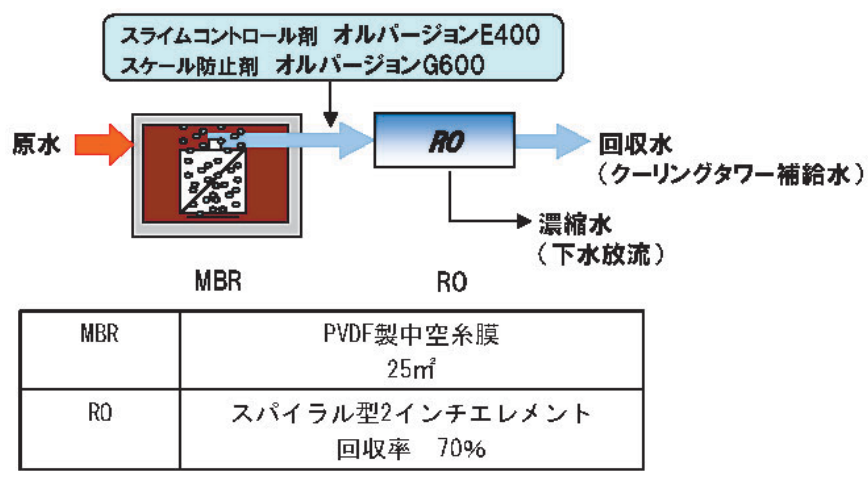

Fig. 2 The experimental flow.

\section{2 試験概要}

Fig. 2 に，本試験の概略フローを示した。下水放流 水を MBR 処理水槽に受け, MBR処理後 ROへ供給す る前に，スライム発生抑制のためにスライムコント ロール剂「オルパージョンE400」を，また無機スケ 一ル発生防止のためにスケール分散剤「オルパージ ヨンG600」（共にオルガノ社製）をそれぞれ添加し た. 下水放流水は, 試験期間中の水質変動があった ものの, 導電率 : $1500 \sim 3000 \mu \mathrm{S} / \mathrm{cm}$ 程度, TOC : $15 \sim 40 \mathrm{mg} / \mathrm{L}$ 程度であった. MBRに用いた膜は, PVDF製浸漬型中空糸膜 (有効膜面積 : $25 \mathrm{~m}^{2}$ ), RO 膜はポリアミド系のスパイラル型 2 インチエレメント を用い，回収率は70\%に設定した。

\section{3. 結 果}

\subsection{MBR 試験データ}

Fig. 3 に, 吸引圧力の推移を示した。初期において は， $0.4 \mathrm{~m} / \mathrm{d}$ の Flux で運転をし，40日間程度安定し て推移した。 その後負荷を高めるため, $0.6 \mathrm{~m} / \mathrm{d}$ の Fluxでの運転に切り替えても, 急激な吸引圧力の上 昇は見られなかった。このことから，本下水放流水 の水質であれば, $0.6 \mathrm{~m} / \mathrm{d}$ 程度の Flux での運用が可 能であると考えられる。

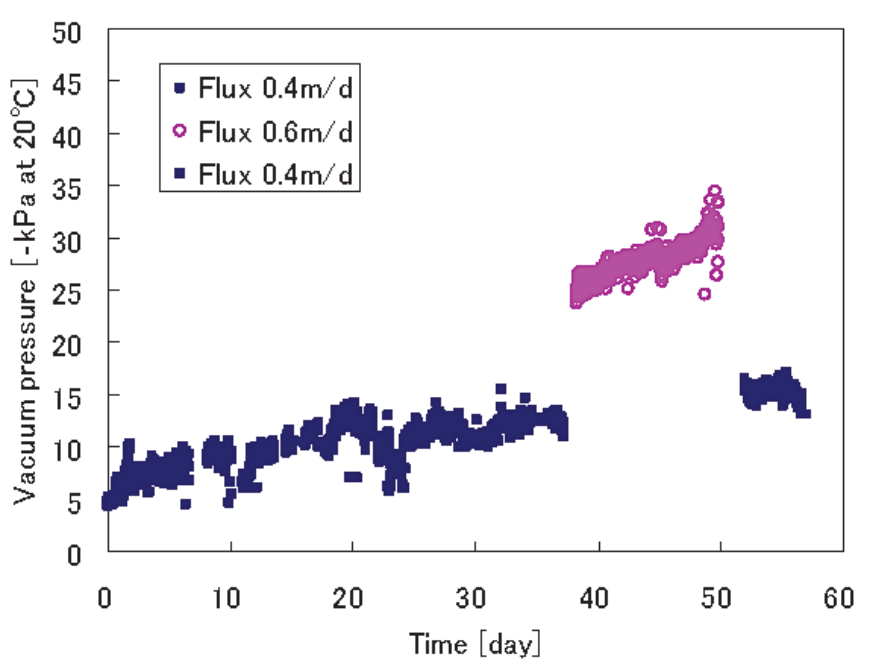

Fig. 3 The vacuum pressure of MBR depending on flux.

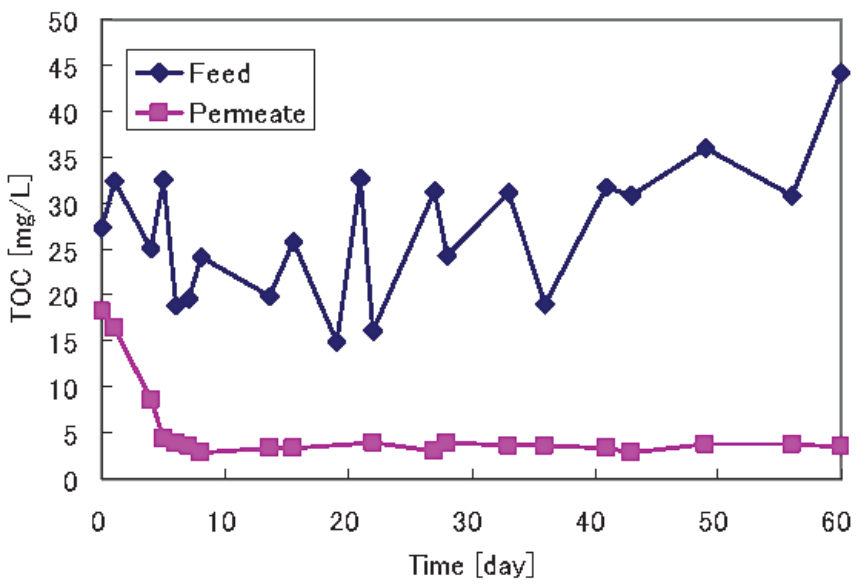

Fig. 4 The feed and permeate TOC concentration of MBR.

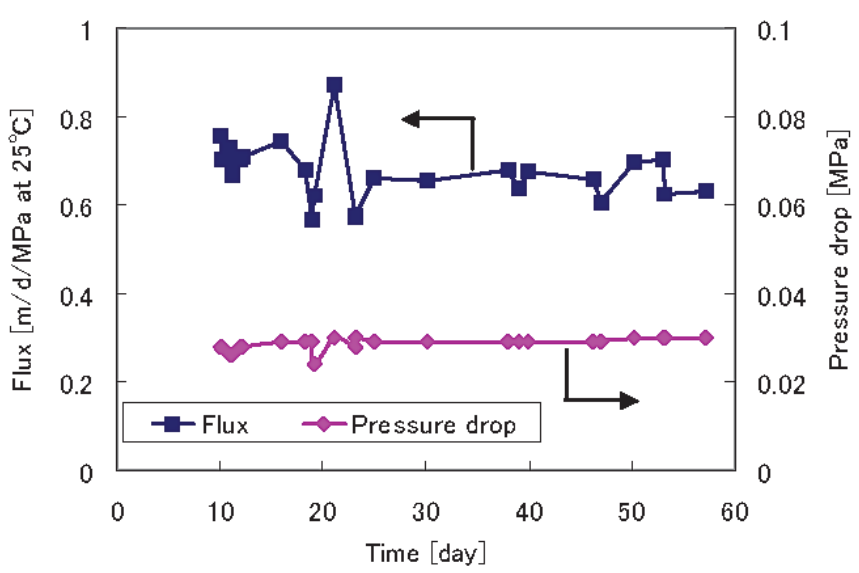

Fig. 5 The flux and pressure drop of RO during the experimental period.

Fig. 4 に, MBR処理前後のTOCの推移を示した. 原水変動はあるものの, MBR処理水においては, ほ ぼ $5 \mathrm{mg} / \mathrm{L}$ 以下の TOC で安定した運転が可能であ つた. 


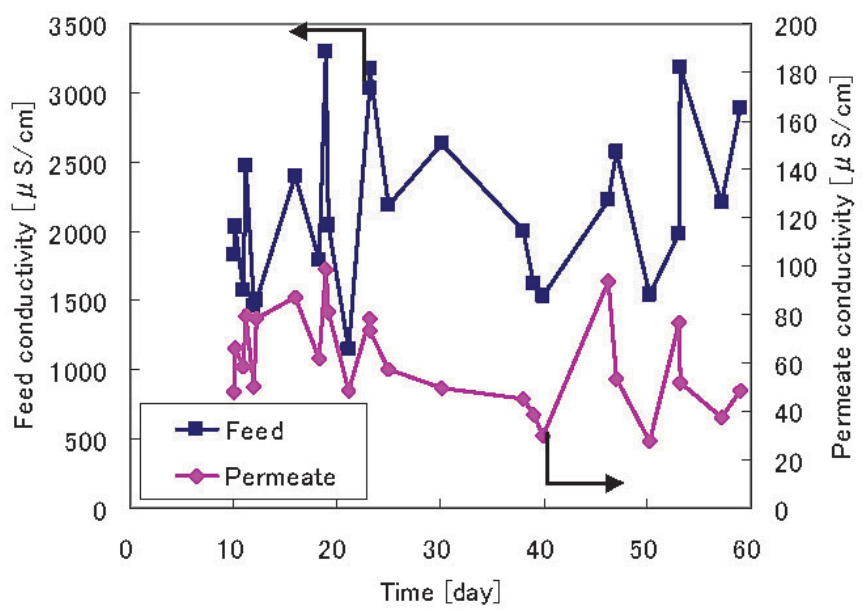

Fig. 6 The feed and permeate electric conductivity of RO.

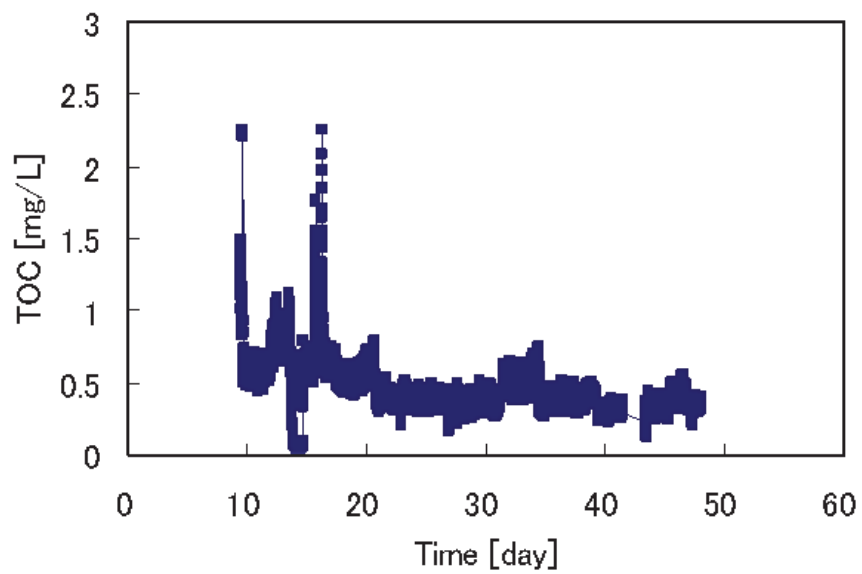

Fig. 7 The relationship between time and TOC of RO permeate.

\subsection{RO 試験データ}

Fig. 5 に，ROにおける通水差圧と Fluxの推移を示 した。本試験期間中, 非常に安定して推移し, 通水 差圧の上昇や，Fluxの低下は見られなかった．通常， MBR 処理水を ROへ通水すると，スライムによる通 水差圧上昇やFlux 低下が起こることが多いが，スラ イムコントロール剤「オルパージョン E400」が, 非 常に大きなスライム抑制作用をもたらしたものと考 えられる。

Fig. 6 にRO 処理前後の導電率の推移を, Fig. 7 に $\mathrm{RO}$ 処理後の TOCの推移を示した. $\mathrm{RO}$ 原水水質に変 動があるものの，RO処理水においては，お打むね導 電率： $100 \mu \mathrm{S} / \mathrm{cm}$ 以下, TOC : $0.5 \mathrm{mg} / \mathrm{L}$ 程度の安定 した水質が得られた。

\section{4. まとめ}

Table 1に，回収原水および各工程処理水の水質を
Table 1 The water quality of each process

\begin{tabular}{|c|c|c|c|}
\hline & 回収原水 & MBR処理水 & $\begin{array}{c}\text { 回収水 } \\
\text { (R0透過水) }\end{array}$ \\
\hline $\mathrm{pH}$ & $6 \sim 7$ & $6 \sim 7$ & $5 \sim 6$ \\
\hline 萁電率 $(\mu \mathrm{S} / \mathrm{cm})$ & $1,500 \sim 3,000$ & $1,500 \sim 3,000$ & $30 \sim 100$ \\
\hline $\mathrm{TOC}(\mathrm{mg} / \mathrm{L})$ & $15 \sim 40$ & $2 \sim 4$ & $0.2 \sim 0.5$ \\
\hline $\mathrm{BOD}(\mathrm{mg} / \mathrm{L})$ & $25 \sim 75$ & $<2$ & $<2$ \\
\hline
\end{tabular}

まとめて示した. 最終的に得られた回収水（RO透過 水）は, 導電率： $100 \mu \mathrm{S} / \mathrm{cm}$ 以下, TOC : $0.5 \mathrm{mg} / \mathrm{L}$ 程度であり, クーリングタワーの補給水として十分 な水質の水が得られた。 また, MBR・RO ともに, 非常に安定した運転が可能であった。

\section{5. おわりに}

国内はもちろん，特に水不足が深刻な海外におい て，排水回収のニーズはますます高まっていくこと が予想される。従来回収が困難であった, 有機系の 産業排水であっても，本報で紹介したような MBR お よびROを用いて，処理・回収ができることが示され た。しかし，排水は工場によって性状がまちまちで あり,さらに水質変動も大きい. どのような排水で あっても, 安定した処理が可能となるよう, さらな る技術の発展に期待したい.

\section{文献}

1) 小田康雄，糸永貴範，川島敏行：「シンガポールにおけ る $\mathrm{MBR}+\mathrm{RO}$ システムの実証テストについて」, 用水と 廃水, 52 (7), 563-568 (2010)

2）松本英希：「シンガポールニューウォーターにおける MF 膜の適用事例」，水環境学会誌，32 (10), 533-536 (2009)

3）小田康雄，糸永貴範，川島敏行：「シンガポールにおけ る下排水再利用 MBR- RO プロセスの実証検討」，第 26 回ニューメンブレンテクノロジーシンポジウム 2009 予 稿集, S8-3-1 (2009)

4）オルガノ株式会社ホームページ http://www.organo. co.jp/product/electron/wastewater.html

5）恵良 彰：「MBR，MBR+RO システムによる産業排水 の回収」，環境浄化技術，10 (3), 38-42 (2011)

6) 恵良 彰, 江口正浩 : 「電子産業における排水回収シス テムの動向」, 第 11 回水環境学会シンポジウム予稿集, p.200 (2008)

7）江口正浩：「産業排水処理分野における膜処理技術の 動向」，環境浄化技術，6 (8), 12-15 (2007)

(Received 20 July 2011;

Accepted 23 August 2011) 